\title{
Analysis of China's Forest Protection Policy from the Perspective of Policy Tools
}

\author{
Ying Zhang ${ }^{1}$, Yi-Luo Wang ${ }^{1} \&$ Ying Duan ${ }^{1}$ \\ ${ }^{1}$ Shandong Technology and Business University, Yantai Shandong, China \\ Correspondence: Ying Zhang, Shandong Technology and Business University, Yantai, Shandong, China. E-mail: \\ 1321247895@qq.com
}

Received: March 20, 2021

Accepted: April 2, $2021 \quad$ Online Published: April 3, 2021

doi:10.5539/par.v10n1p47

URL: http://dx.doi.org/10.5539/par.v10n1p47

\begin{abstract}
From the perspective of policy tools, this paper using content analysis to analyze 43 central-level policy texts related to forest protection from 1990 to 2016, and divides forest protection policy tools into 16 items and 4 major types. Research conclusion: Among the four policy tools, command-and-control policy tools are used the most, followed by economic incentives, and the use of information disclosure and voluntary participation policy tools is relatively inadequate. Based on the above conclusions, this paper makes the following suggestions: To increase the use of economic incentives, information disclosure and voluntary participation policy tools, it is also possible to strengthen the use of information disclosure and voluntary participation policy tools through reasonable system design. In the newly implemented forestry ecological poverty alleviation field, explore and introduce new forestry ecological poverty alleviation policies and new mechanisms based on public participation, and comprehensively enhance the policy demonstration role of forestry in building a long-term poverty alleviation mechanism.
\end{abstract}

Keywords: forest protection, policy tools, policy text, content analysis

\section{Introduction}

As the main body of the terrestrial ecosystem, forests play a vital role in the service functions of the global ecosystem, providing a series of important service functions such as maintaining biodiversity, soil and water conservation, as well as global carbon and water cycles and climate regulation. However, after entering the new era, due to rapid population growth and economic development, the demand for food, energy, and construction land has increased. Forests have gradually been replaced by land types such as farmland and artificial buildings, resulting in more than $50 \%$ of the world's forests (Chaoran Chen 2018) has been lost. The reduction of forest area will affect ecosystem services and cause a series of ecological problems. Now, global warming has had a significant impact on the global ecosystem and socio-economic system. The earth's ecosystem is like the human body, and a change of just one or two degrees Celsius can lead to catastrophic consequences. Therefore, the protection of forests has become an unshirkable responsibility of people all over the world.

In October 2017, the report of the 19th National Congress of the Communist Party of China promoted the construction of ecological civilization as a "millennium plan", opening up a new era of China's forestry ecological civilization construction and modern development. China's research on the types and functions of policy tools in the field of forest protection has not yet been fully developed. Moreover, domestic research on the types of policy tools is mainly based on foreign policy tool theories and research methods, and comparative studies on the types of policy tools and the role of policy tools applicable to different areas of forest protection in China are relatively lacking. It has become an urgent issue to grasp quantitatively and systematically, through the method of policy text analysis, the pattern of promulgation of forest protection policies at the central level in China, to understand systematically and scientifically the areas of application of different types of forest protection policy tools, and then to select forest protection policy tools scientifically for the governance of ecological and forest protection issues.

The comprehensive use of a combination of different policy tools to maximize the effectiveness of forest protection policies is one of the key points for successfully coping with the problem of forest fragmentation. This article attempts to use policy tool theory and policy text measurement methods to systematically sort out relevant policy texts of forest protection, analyze the classification and characteristics of forest protection policy tools, and provide suggestions for forest protection policy optimization. 


\section{Literature Review}

Policy tools are a series of measures aimed at common problems. The use of policy tools reflects the value concept of policy makers, mainly to achieve specific policy goals (Wei Zang 2018). As a way to improve the efficiency of government work, policy tools developed rapidly in the West in the 1970s under the impetus of global integration and the information revolution (Zhenming Chen 2007). Different scholars have different opinions on the classification of policy tools. This article summarizes them as different standards from multiple perspectives. According to the intensity of government intervention and the degree of market autonomy, Howlett designed three types of policy tools: compulsory, resource-based, and mixed (Howlett M 2009). Based on the policy background, purpose and implementation effect, McDonnell summarized policy tools as incentive, command, learning and system (McDonnell L M 1987). Rothwell classifies policy instruments as supply-based, environmental and demand-based according to the hierarchy of policy effects on science and technology activities (Rothwell R 1981).

The study of policy tools by Chinese scholars began at the end of the 20th century, and started late compared to Western scholars. With the continuous transformation of government functions in china, new challenges have arisen to reform government management methods and improve government efficiency, which also puts forward higher requirements for the study of policy tools. Scholars in different disciplines have repeatedly conducted a large number of empirical research on public policy. Therefore, researching public policy from the perspective of instrumental rationality has become a trend in the academic world (Jianguang Gu 2007). In China, the theory of policy instruments has been widely used in public product supervision, energy, social welfare and other fields. For example, Xiaofan Wang conducted a quantitative analysis of China's farmland ecological management policy text from the perspective of policy tools. They believe that there are too many tools for farmland ecological management and protection policy, capacity building tools, symbolic and admonishing tools, and incentive tools, authoritative tools, and systems. The tools of change need to be strengthened (Xiaofan Wang 2018). Jun Yao have studied China's pension service policy tools found that there is a structural imbalance in the application of basic policy tools, and the effectiveness of policy tools has not been fully reflected. From the perspective of improving the accuracy of policy targeting, continue to improve and optimize the use of policy tools of the pension service policy (Jun Yao 2018). Cui Huang used the content analysis method to analyze the policy instruments used in the wind energy policies enacted by the Chinese government, and found that there is a certain discontinuity in the wind energy policy, and there are certain conflicts in the use of wind energy policy tools (Cui Huang 2011). Regarding the types of policy tools, there are 10 types of tool classification based on the "strong and weak" level of government involvement (Chengfu Zhang 2005), and three types of tool classification based on the development of modern management technology (Zhenming Chen 2005). Based on the research results of the Organization for Economic Cooperation and Development and the World Bank, Dan Pan and Fanbin Kong classified China's forestry policy tools into four categories: command and control, economic incentives, information disclosure and voluntary participation (Dan Pan 2019).

\section{Methodology and Methods of Data Collection}

\subsection{Research methods}

The content analysis method is a research tool to obtain conclusions through objective, systematic and quantitative analysis of "content" including text, audio, video, photos, surveys, etc. This paper uses this method to analyze the Chinese forest protection policy text at the central level, so as to put forward suggestions for China's forest protection.

\subsection{Research Tools}

In order to improve the accuracy, science and validity of the content analysis, Nvivo software was chosen as the analysis tool. It is a very powerful qualitative analysis software with a range of functions such as coding, querying and classification that help the user to read the text quickly and produce results.

\subsection{Policy Text Source}

Established in 1985, Beida Law Database is the most comprehensive database of policies and regulations in China.This article uses 1990-2016 as the time interval and "returning farmland to forests" as the content keyword to search the Peking University magic weapon database. A total of 42 central regulations and judicial interpretations related to the content of returning farmland to forests were retrieved, and 777 local laws and regulations were retrieved. 1 piece of draft legislation, 1 piece of regulation interpretation; searched with "tree planting and afforestation" as the content keyword, and retrieved 3 central regulations and judicial interpretations and 129 local regulations and rules; searched with "forest logging" as the content keyword, altogether 25 judicial interpretations of central regulations and 171 local regulations were retrieved. Because forest protection policies 
in various regions are based on the relevant central policies, and the lack of automatic policy text analysis software at the current stage, it is difficult to conduct large-scale policy text analysis. This article only conducts a text quantitative analysis of the central level forest protection policies. After excluding duplicate and irrelevant texts, a total of 43 central-level forest protection policy texts from 1990 to 2016 were obtained.

\subsection{Policy Text Coding}

In order to conduct a more detailed study on the legal texts of forest protection, this article imported 43 policy texts from 1990 to 2016 into NVivo, and initially coded all those related to "returning farmland to forests", "forestation" and "forest logging". (Table 1), a total of 59 code points were obtained.

Table 1. Coding example

\begin{tabular}{|c|c|}
\hline Key words & Content description \\
\hline Logging quota & $\begin{array}{l}\text { Vigorously strengthen the protection and } \\
\text { management of forest resources, implement } \\
\text { the logging quota system in accordance with } \\
\text { the law, strictly control the consumption of } \\
\text { forest resources, improve the efficiency of } \\
\text { forest resource utilization, and promote the } \\
\text { preparation and implementation of forest } \\
\text { management plans. This is important for } \\
\text { establishing a sound forestry ecosystem, a } \\
\text { developed forestry industry system, and a } \\
\text { prosperous forest industry. The ecological } \\
\text { cultural system is of great and far-reaching } \\
\text { significance in coping with global climate } \\
\text { change and promoting sustainable economic } \\
\text { and social development. }\end{array}$ \\
\hline
\end{tabular}

Subsidies for Adhering to the policy of returning farmland returning to forests, the state provides grain subsidies farmland to to households returning farmland free of forest and charge.

grassland

Respect the On the basis of fully investigating and
wishes of solving the livelihoods of the local people, all farmers
Notice of the General Office of the State Council on Improving the Methods of Grain Subsidy for Returning Farmland to Forests (Guobanfa [2004] No. 34 on April 13, 2004) relevant provinces can take into account the needs of protecting historical and cultural heritage, and put forward the demand for returning farmland to forests and pastures on the premise of respecting the wishes of farmers.
Notice of the Ministry of Finance, the National Development and Reform Commission, the State Forestry Administration, the Ministry of Land and Resources, the Ministry of Agriculture, the Ministry of Water Resources, the Ministry of Environmental Protection, and the Poverty Alleviation Office of the State Council on expanding the scale of the new round of returning farmland to forests and grasslands (Cainong [2015] No.258 )

\begin{tabular}{ll}
\hline Information & Townships (towns) and villages that \\
disclosure & implement the conversion of farmland to \\
& forests shall establish a publicity system for \\
& returning farmland to forests, and publicize \\
& the area, afforestation tree species, survival \\
& rates, and grants of funds and grain subsidies \\
& for those who are returning farmland to \\
& forests.
\end{tabular}

Regulations on Returning Farmland to Forests

(Promulgated by Decree No. 367 of the State Council of the People's Republic of China on December 14, 2002, revised in accordance with the "Decision of the State Council on Amending Some Administrative Regulations" on February 6, 2016) 
Preliminary coding results show (Figure 1) that among 59 coding points, the proportion of "strictly following regulations" is the highest, about $40.8 \%$; the proportion of "cutting quota" and "returning farmland to forests subsidies" follows closely behind. They were $20.2 \%$ and $11.4 \%$ respectively. Among them, "in strict accordance with regulations" refers to the "preparation of the provincial implementation plan for returning farmland to forests in strict accordance with the relevant national requirements, and strict legal disposal", without specifying how to implement it; "returning farmland to forests (grass) subsidies" "Mainly includes content such as "the state provides grain subsidies and cash subsidies to returning farming households without compensation"; "harvesting quota" mainly refers to content related to "restricted logging quota, restricted logging time, scope, intensity" and so on.

\begin{tabular}{|c|c|c|c|}
\hline \multirow[t]{2}{*}{ Strictly follow the regulations } & \multicolumn{2}{|c|}{$\begin{array}{l}\text { Subsidies for } \\
\text { farmland to foturning } \\
\text { grassland }\end{array}$} & \multirow{2}{*}{$\begin{array}{l}\text { Accountability } \\
\text { according } \\
\text { to law } \\
\begin{array}{c}\text { Punish according } \\
\text { to law }\end{array}\end{array}$} \\
\hline & $\begin{array}{l}\text { Policy } \\
\text { guidance, } \\
\text { voluntary } \\
\text { priority }\end{array}$ & $\begin{array}{l}\text { Reduce } \\
\text { agricultural } \\
\text { taxes }\end{array}$ & \\
\hline \multirow[t]{2}{*}{ Logging quota } & $\begin{array}{l}\text { Encourage } \\
\text { self-operated } \\
\text { forestry }\end{array}$ & $\begin{array}{c}\text { Strict } \\
\text { management }\end{array}$ & \\
\hline & $\begin{array}{l}\text { Public forest } \\
\text { registration }\end{array}$ & No logging & \\
\hline
\end{tabular}

Figure 1. Hierarchical structure diagram of code points (area represents quantity)

Source: Author's self-made

\section{Discussion of Results}

\subsection{Classification of Forest Protection Policy Tools}

This paper divides the classification and induction of forest protection policy tools into two steps. First, summarize the forest protection policy tools from 59 policy text coding and clustering results. Then, comprehensively classify the principles of policy tools, and combine the specific characteristics of forest protection to classify the types of forest protection policy tools. After classification, policy tools can be divided into 16 items and 4 types (Table 2). 
Table 2. Classification of forest protection policy tools

\begin{tabular}{cc}
\hline Types of policy tools & Specific classification \\
\hline Command control type & Strictly follow the regulations \\
Accountability according to law & Logging quota \\
& Strictly manage special funds \\
No logging
\end{tabular}

Source: Author's self-made

Command-controlled policy tools refer to mandatory and binding policy measures implemented by administrative management methods, such as logging ban, logging quota system, strict compliance with regulations, and timber logging specifications, which are command-controlled policy tools. Economic incentive policy instruments are those that use economic measures to influence the decisions of 'economic agents', such as fines for forest damage, tax incentives, subsidies for returning farmland to grass, and low-interest credit support. Voluntary participation policy tools refer to policy measures that the state proposes and suggestions, and individuals and companies voluntarily choose whether to participate. For example, encouraging returning farmland to forest (returning grassland), respecting farmers' wishes, and encouraging self-run forestry are all voluntary participation policy tools. Information disclosure policy tools are policy measures that the state proactively discloses information to the public during the exercise of management powers, and is supervised by the public. For example, public forest registration, punishment disclosure, subsidy policy disclosure, public reporting mailboxes and other reporting methods, supervision Inspection disclosure is an information disclosure policy tool.

\subsection{Features of Forest Protection Policy Tools}

(1) The country has different proportions of the four policy tools used in forest protection: command and control, economic incentive, voluntary participation, and information disclosure (Figure 2). Among them, command and control policy tools are used more, such as strict compliance with regulations and logging quotas, accounting for $40.8 \%$ and $20.2 \%$ respectively. In the current absence of effective forest protection measures, this could act as an effective deterrent for the relevant enforcement authorities and farmers to avoid the fragmentation of forests caused by over-harvesting and poor enforcement. Economic incentive policy tools include positive incentives for farmers returning farmland to forests (subsidies for returning farmland to forests) and negative incentives for executives from relevant departments due to poor implementation (penalties in accordance with the law). In comparison, the subsidies given to farmers returning farmland to forests accounted for a relatively large amount (11.4\%), which can encourage farmers to return farmland to forests, and at the same time provide certain economic or grain compensation to farmers who have already returned farmland to forests and improve their living standards. Negative incentives for relevant executive departments can play a preventive role, but if they are used less, the effect may not be too obvious. Voluntary participation policy tools and information disclosure policy tools are used less frequently than the former two (As can be seen from Figure 2, the use of voluntary participation policy tools accounted for $8.78 \%$, and information disclosure policy tools accounted for $4.82 \%$ ). Government departments can 
increase their attention to these two aspects, so as to respect the wishes of farmers and increase the transparency of law enforcement.

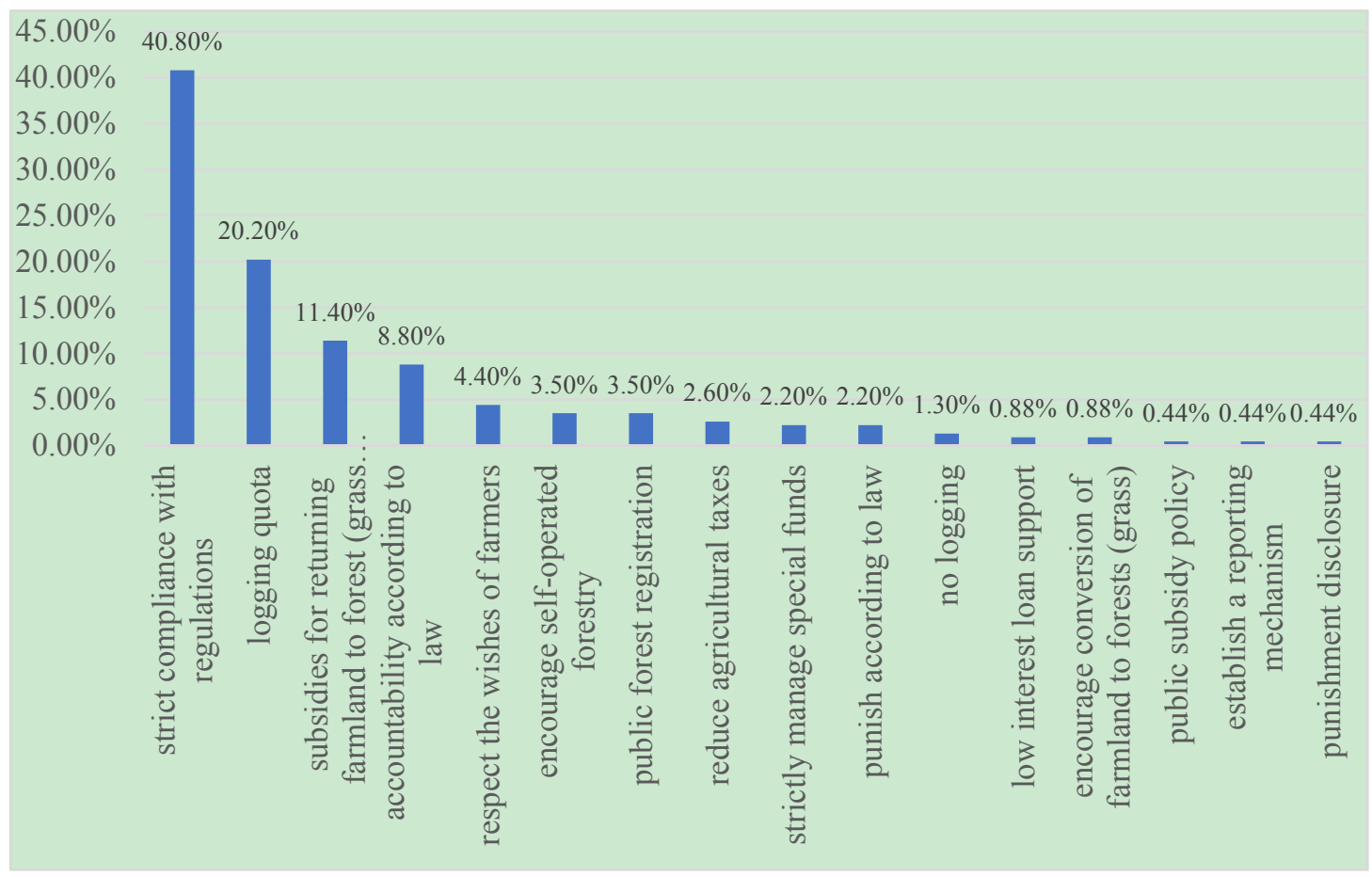

Figure 2. Proportion of forest protection policy tools

Source: Author's self-made

(2) Policy tools evolve over time, and the proportion of command-and-control policy tools continues to rise. As shown in Figure 3, policy tools have been enriched over time. This paper uses 2000 and 2005 as the time node to divide the evolution of forest protection policy tools into three stages.

The first stage: 1990-2000. It can be seen intuitively from the figure that there are fewer policies related to various policy tools at this stage. At this time, command control and economic incentives are the main ones, and there are zero policies related to information disclosure. This period was in a period of sustainable development of forestry development. What is more special is that since 1995, economic incentive policy tools have begun to rise year by year, mainly with negative incentives. One of the representative ones is that the relevant notices on forest logging issued during this period clearly added the "penalties": Those who commit one of the following acts shall be punished in accordance with Article 39 of the Forest Law and the relevant provisions of the Forest Law Implementation Regulations : (1) State-owned enterprises, public institutions and collectively-owned units have not obtained forest logging permits, felling trees without authorization, or the annual timber output exceeds $5 \%$ of the amount specified in the logging permit; (2) State-owned enterprises and institutions fail to follow the approved logging Design documents where the area for cutting operations accounts for more than $5 \%$ of the approved operation area; when the collectively-owned unit performs logging in accordance with the provisions of the forest logging license, the operation area that does not meet the logging quality requirements accounts for more than 5\% of the approved operation area; (3) Individuals who have not obtained a forest felling permit, cut forests without authorization, or violated the number, location, method, and tree species specified in the forest felling permit, and the felled forests exceed half a cubic meter. Punishment of illegal activities related to forest logging can effectively avoid excessive logging of forests and strengthen forest protection.

The second stage: 2000-2005. Since 2000, no matter which kind of policy tool is the main policy tool, the policy text on forest protection has begun to increase substantially. This is closely related to the extreme floods that occurred in the Yangtze, Nenjiang, and Songhua River basins in the late 1990s and caused extremely serious losses. The government made major adjustments to forestry policies, and the number of regulatory documents related to forestry reached a peak in 2000. What is unique about this period is the emergence of policy texts involving information disclosure-type policy tools, the representative of which is the "Regulations on Returning Farmland 
to Forests" promulgated in 2002. Article 46 of the regulations clearly stipulates that townships and villages that implement the conversion of farmland to forests shall establish a publicity system for the conversion of farmland to forests, and the area of conversion of farmland to forests, afforestation tree species, survival rate, funds and food subsidies The distribution and other information will be publicized. This shows that the country has begun to attach importance to the openness and transparency of information. Disclosure of information can realize the public's supervision of the government, which is the only way to build a clean, efficient, and rule of law government.

The third stage: 2005-2015. During this period, forestry modernization has become the focus of China's forestry policy. The number of correspondingly newly issued forestry policy documents has increased exponentially compared with the past. The use of policy instruments is generally characterised by an increasing diversity, most notably in the number of command-and-control policy texts, accounting for $48.15 \%$ (Figure 3 ), which mainly focus on the implementation of relevant affairs in strict accordance with regulations on the requirements of relevant department personnel.

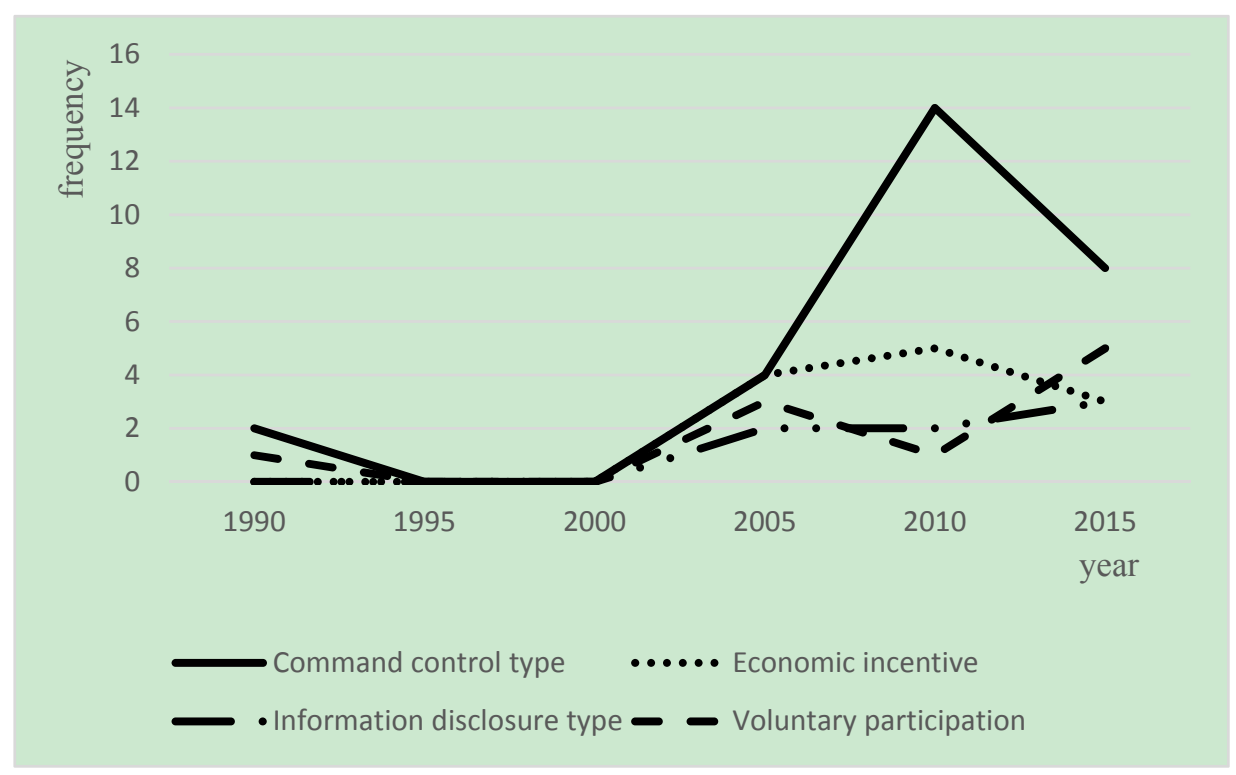

Figure 3. The evolution of forest protection policy tools

Source: Author's self-made

\section{Conclusions and Recommendation}

From the perspective of policy tools, this paper conducts a quantitative analysis of 43 central-level forest protection policy texts from 1990 to 2016, and divides forest protection policy tools into 16 items and 4 major types.

The finding of the research shows that China's forest protection policy tools cover four types: command and control, economic incentives, information disclosure, and voluntary participation. The diversification of the use of policy tools continues to increase. Among them, command-and-control policy tools are the most commonly used policy tools for the government to control and manage forestry, followed by economic incentives. The use of information disclosure and voluntary participation policy tools is relatively insufficient, and multiple policy tools are used in combination. It needs to be strengthened. As time evolves, policy tools are used more and more frequently. It is more obvious that the use frequency of command and control policy tools and economic incentive policy tools has increased significantly. Among them, economic incentive policy tools have gone from scratch, and quickly surpassed the use of information disclosure and voluntary participation policy tools.

Based on the above conclusions, the following recommendation can be forwarded: increase the use of economic incentive, information disclosure, and voluntary participation policy tools. For example, following the principle of "beneficiary compensation", the ecological compensation mechanism in forest protection should be further improved, and provide subsidies or rewards for environmentally friendly forestry production and living activities, so as to effectively increase the enthusiasm of forestry protection. It is also possible to strengthen the use of information disclosure and voluntary participation policy tools through reasonable system design. In the newly implemented forestry ecological poverty alleviation field, it is possible to explore and introduce new forestry 
ecological poverty alleviation policies and new mechanisms based on public participation, so as to comprehensively improve the forestry industry. Establish a policy demonstration role in a long-term mechanism for poverty alleviation.

\section{References}

Chen, C. R., \& Wang, K. (2018). The world's forest area is shrinking day by day. Ecological Economy, 34(09), 25.

Chen, Z. M. (2005). Public Policy Analysis. Beijing: China Renmin University Press.

Chen, Z. M., \& Xue, L. (2007). The key fields and topics of the theoretical research on public management in China. Chinese Social Sciences, (03), 140-152+206.

Gu, J. G., \& Wu, M. H. (2007). On the Perspective of Public Policy Instrumentalism. Studies in Science of Science, (01), 47-51.

Howlett, M., Ramesh, M., Perl, A. (2009). Studying public policy: Policy cycles and policy subsystems. Oxford: Oxford University Press.

Huang, C., Su, J., Shi, L. P., \& Cheng, X. T. (2011). A quantitative study of Chinese wind energy policy text from the perspective of policy tools. Studies in Science of Science, 29(06), 876-882+889.

McDonnell, L. M., \& Elmore, R. F. (1987). Getting the job done: Alternative policy instruments. Educational Evaluation and Policy Analysis, 9(2), 133-152. https://doi.org/10.3102/01623737009002133

Pan, D., Chen, H., \& Kong, F. B. (2019). Research on the evolution characteristics and laws of China's forestry policy since 1949 - Based on a quantitative analysis of 283 forest-related regulatory documents. China Rural Economy, (07), 89-108.

Rothwell, R., \& Zegveld W. (1981). Industrial innovation and public policy: Preparing for the 1980s and 1990s. London: Frances Printer.

Wang, X. F., Hao, L., Qin, H. B., Su, L. Y., \& Liu, Z. N. (2018). Quantitative Research on Chinese Cultivated Land Ecological Management Policy Text from the Perspective of Policy Tools. China Land Science, 32(12), 1523.

Yao, J., \& Zhang, L. (2018). Quantitative research on the text of China's pension service policy from the perspective of policy tools. Modern Economic Research, (12), 33-39.

Zang, W., Li, T. T., \& Xu, L. (2018). Research on Mining and Quantitative Evaluation of Supporting Policy Tools for Makerspace Space in Beijing. Soft Science, 32(9), 56-61.

Zhang, C. F. (2005). Public Administration. Beijing: Renmin University of China Press.

\section{Appendix}

\begin{tabular}{ccl}
$\begin{array}{c}\text { Serial } \\
\text { number }\end{array}$ & Years & \multicolumn{1}{c}{ Policy text name } \\
\hline 1 & 1973 & Renewal Regulations for Forest Harvesting (FBM-CLI-4-372) \\
\hline 2 & 1980 & $\begin{array}{l}\text { Instructions of the Central Committee of the Communist Party of China } \\
\text { and the State Council on Vigorously Carrying out Tree Planting and } \\
\text { Afforestation (FBM-CLI-16-679) }\end{array}$ \\
\hline 3 & 1982 & $\begin{array}{l}\text { Notice of the State Council and the Central Military Commission on } \\
\text { Printing and Distributing the "Afforestation and Forest Management } \\
\text { Measures in Military Barracks" (FBM-CLI-7-1478) }\end{array}$ \\
\hline 5 & 1985 & $\begin{array}{l}\text { Establish interim regulations on annual forest logging quotas (FBM-CLI- } \\
\text { 4-88015) }\end{array}$ \\
\hline 6 & 1987 & $\begin{array}{l}\text { Notice of the State Council on Approving and Transmitting the Ministry of } \\
\text { Forestry's Report on the Audit Opinions of the Annual Forest Logging } \\
\text { Quota of Provinces, Autonomous Regions and Municipalities (FBM-CLI- } \\
\text { 2-234560) }\end{array}$ \\
\hline
\end{tabular}




\begin{tabular}{|c|c|c|}
\hline & & CLI-2-3478) \\
\hline 7 & 1989 & $\begin{array}{l}\text { Notice of the Ministry of Forestry on Effectively Strengthening the } \\
\text { Management of Annual Forest Logging Quota (FBM-CLI-4-87609) }\end{array}$ \\
\hline 8 & 1990 & $\begin{array}{l}\text { Notice of the State Council on Approving and Transmitting the Ministry of } \\
\text { Forestry's Report on the Audit Opinions of the Annual Forest Logging } \\
\text { Quota during the "Eighth Five-Year Plan" Period of Provinces, } \\
\text { Autonomous Regions and Municipalities (FBM-CLI-2-318921) }\end{array}$ \\
\hline 9 & 2000 & $\begin{array}{l}\text { Notice of the Ministry of Finance and the State Administration of Taxation } \\
\text { on the Agricultural Tax Policy in Pilot Areas of Returning Farmland to } \\
\text { Forests and Grasslands (FBM-CLI-4-31994) }\end{array}$ \\
\hline 10 & 2000 & $\begin{array}{l}\text { Notice of the Ministry of Finance and other seven departments on the } \\
\text { issuance of the Interim Measures for the Financial and Financial } \\
\text { Management of Grain Subsidy Funds for the Pilot Project of Returning } \\
\text { Farmland to Forests and Grasslands (FBM-CLI-4-31880) }\end{array}$ \\
\hline 11 & 2000 & $\begin{array}{l}\text { Several Opinions of the State Council on Further Promoting the Pilot Work } \\
\text { of Returning Farmland to Forests and Grasslands (FBM-CLI-2-31358) }\end{array}$ \\
\hline 12 & 2001 & $\begin{array}{l}\text { Notice of the State Administration of Taxation on the Issue of Exemption } \\
\text { of Value-Added Tax on Subsidy Grain for Returning Farmland to Forests } \\
\text { and Grasslands (FBM-CLI-4-38325) }\end{array}$ \\
\hline 13 & 2001 & $\begin{array}{l}\text { Notice of the State Council on Approving and Transmitting the State } \\
\text { Forestry Administration's Report on the Audit Opinions of the Annual } \\
\text { Forest Logging Quotas of Provinces, Autonomous Regions and } \\
\text { Municipalities During the "Tenth Five-Year Plan" Period (FBM-CLI-2- } \\
\text { 34965) }\end{array}$ \\
\hline 14 & 2002 & $\begin{array}{l}\text { Notice of the State Forestry Administration on Doing a Good Job in } \\
\text { Returning Farmland to Forests in } 2002 \text { (FBM-CLI-4-62727) }\end{array}$ \\
\hline 15 & 2002 & $\begin{array}{l}\text { Several Opinions of the State Council on Further Improving Policies and } \\
\text { Measures for Returning Farmland to Forests (FBM-CLI-2-40250) }\end{array}$ \\
\hline 16 & 2002 & Regulations on Returning Farmland to Forests (FBM-CLI-2-44329) \\
\hline 17 & 2003 & $\begin{array}{l}\text { Notice of the National Grain Administration on Further Doing a Good Job } \\
\text { in the Grain Supply of Returning Farmland to Forests (FBM-CLI-4-47428) }\end{array}$ \\
\hline 18 & 2004 & $\begin{array}{l}\text { Notice of the Office of the State Forestry Administration on Carrying out } \\
\text { the National Afforestation Quality Inspection Work in } 2004 \text { (FBM-CLI-4- } \\
55359 \text { ) }\end{array}$ \\
\hline 19 & 2004 & $\begin{array}{l}\text { Notice of the General Office of the State Council on Improving the } \\
\text { Measures for Grain Subsidy for Returning Farmland to Forests (FBM-CLI- } \\
\text { 2-52939) }\end{array}$ \\
\hline 20 & 2005 & $\begin{array}{l}\text { Notice of the Office of the State Forestry Administration on Carrying out } \\
\text { the } 2005 \text { Afforestation Quality Inspection Work (FBM-CLI-4-57488) }\end{array}$ \\
\hline 21 & 2005 & $\begin{array}{l}\text { Notice of the General Office of the State Council on Effectively Doing Well } \\
\text { the "Five Combinations" and Further Consolidating the Achievements of } \\
\text { Returning Farmland to Forests (FBM-CLI-2-58478) }\end{array}$ \\
\hline 22 & 2005 & $\begin{array}{l}\text { Notice of the State Council on Approving and Transmitting the Opinions } \\
\text { of the State Forestry Administration on the Annual Forest Logging Quota } \\
\text { during the "Eleventh Five-Year Plan" period in various regions (FBM-CLI- } \\
\text { 2-73651) }\end{array}$ \\
\hline 23 & 2007 & $\begin{array}{l}\text { Notice of the Ministry of Finance, the Office of the Western Region } \\
\text { Development Leading Group of the State Council, and the National } \\
\text { Development and Reform Commission on Issuing the "Special Funds and } \\
\text { Management Measures for Consolidating the Achievements of Returning }\end{array}$ \\
\hline
\end{tabular}




\begin{tabular}{|c|c|c|}
\hline & & Farmland to Forests" (FBM-CLI-4-110565) \\
\hline 24 & 2007 & $\begin{array}{l}\text { Notice of the Ministry of Finance on Issuing the Measures for Improving } \\
\text { the Management of the Policy and Subsidy Funds for Returning Farmland } \\
\text { to Forests (FBM-CLI-4-103468) }\end{array}$ \\
\hline 25 & 2007 & $\begin{array}{l}\text { Measures for the Use and Management of Special Funds for Consolidating } \\
\text { the Achievements of Returning Farmland to Forests (FBM-CLI-4-168302) }\end{array}$ \\
\hline 26 & 2007 & $\begin{array}{l}\text { Notice of the State Forestry Administration on further improving the } \\
\text { current work of returning farmland to forests (FBM-CLI-4-89822) }\end{array}$ \\
\hline 27 & 2007 & $\begin{array}{l}\text { Notice of the State Council on Improving the Policy of Returning Farmland } \\
\text { to Forests (FBM-CLI-2-96317) }\end{array}$ \\
\hline 28 & 2008 & $\begin{array}{l}\text { Notice of the Ministry of Finance on Doing a Good Job in the Management } \\
\text { of the Special Account of Subsidy Funds for Returning Farmland to Forests } \\
\text { (FBM-CLI-4-107400) }\end{array}$ \\
\hline 29 & 2008 & $\begin{array}{l}\text { Notice of the State Forestry Administration on Carrying out the Pilot Forest } \\
\text { Logging Management Reform (FBM-CLI-4-112205) }\end{array}$ \\
\hline 30 & 2009 & $\begin{array}{l}\text { Notice of the Ministry of Finance and the State Forestry Administration on } \\
\text { Issuing the "Administrative Measures for the Central Finance Forest } \\
\text { Ecological Benefit Compensation Fund" (Revised in 2009) (FBM-CLI-4- } \\
\text { 219688) }\end{array}$ \\
\hline 31 & 2010 & $\begin{array}{l}\text { Notice of the State Forestry Administration on Further Deepening the Pilot } \\
\text { Work of Forest Logging Management Reform (FBM-CLI-4-140360) }\end{array}$ \\
\hline 32 & 2011 & $\begin{array}{l}\text { Opinions of the Ministry of Finance and the State Forestry Administration } \\
\text { on Carrying out the Pilot Program of Subsidies for Forest Trees in } 2011 \\
\text { (FBM-CLI-4-154463) }\end{array}$ \\
\hline 33 & 2011 & $\begin{array}{l}\text { Opinions of the Ministry of Finance and the State Forestry Administration } \\
\text { on the Pilot Program of Afforestation Subsidies in } 2011 \text { (FBM-CLI-4- } \\
\text { 153242) }\end{array}$ \\
\hline 34 & 2011 & $\begin{array}{l}\text { Notice of the State Forestry Administration on the implementation of the } \\
\text { "Notice of the State Council to Approve and Transmit the Forestry } \\
\text { Administration's Opinions on the National Annual Forest Logging Quota } \\
\text { during the Twelfth Five-Year Plan Period" (FBM-CLI-4-149032) }\end{array}$ \\
\hline 35 & 2011 & $\begin{array}{l}\text { Notice of the State Council on Approving and Transmitting the Opinions } \\
\text { of the National Forestry Administration on the Annual Forest Logging } \\
\text { Quota during the National "Twelfth Five-Year Plan" (FBM-CLI-2-150232) }\end{array}$ \\
\hline 36 & 2011 & $\begin{array}{l}\text { Measures for the Administration of Forest Harvesting and Renewal } \\
\text { (Revised in 2011) (FBM-CLI-2-174500) }\end{array}$ \\
\hline 37 & 2015 & $\begin{array}{l}\text { Notice of the Ministry of Finance, the National Development and Reform } \\
\text { Commission, and the State Forestry Administration on expanding the scale } \\
\text { of returning farmland to forests and grasslands in a new round (FBM-CLI- } \\
\text { 4-264019) }\end{array}$ \\
\hline 38 & 2015 & $\begin{array}{l}\text { Notice of the General Office of the National Development and Reform } \\
\text { Commission, the General Office of the Ministry of Finance, and the Office } \\
\text { of the State Forestry Administration on accelerating the implementation of } \\
\text { the new round of returning farmland to forests and grasslands (FBM-CLI- } \\
\text { 4-257784) }\end{array}$ \\
\hline 39 & 2015 & $\begin{array}{l}\text { Notice of the State Forestry Administration on Doing a Good Job in } 2015 \\
\text { Forest Logging Management in Key State-owned Forest Regions in } \\
\text { Northeast Inner Mongolia (FBM-CLI-4-240222) }\end{array}$ \\
\hline 40 & 2016 & $\begin{array}{l}\text { Notice of the National Development and Reform Commission, the Ministry } \\
\text { of Finance, and the State Forestry Administration on issuing the } 2016\end{array}$ \\
\hline
\end{tabular}


annual task of returning farmland to forests and grasslands (FBM-CLI-4276862)

\begin{tabular}{ccl}
\hline \multirow{2}{*}{2016} & $\begin{array}{l}\text { Notice of the State Forestry Administration on Effectively Strengthening } \\
\text { the Management of Annual Forest Logging Quota during the "Thirteenth } \\
\text { Five-Year Plan" (FBM-CLI-4-288635) }\end{array}$ \\
\hline 42 & 2016 & $\begin{array}{l}\text { The State Council's Reply on the Annual Forest Logging Quota during the } \\
\text { National "Thirteenth Five-Year Plan" (FBM-CLI-2-264168) }\end{array}$ \\
\hline 43 & 2016 & $\begin{array}{l}\text { Regulations on Returning Farmland to Forests (2016 Revision) (FBM-CLI- } \\
\text { 2-267193) }\end{array}$ \\
\hline
\end{tabular}

\section{Copyrights}

Copyright for this article is retained by the author(s), with first publication rights granted to the journal.

This is an open-access article distributed under the terms and conditions of the Creative Commons Attribution license (http://creativecommons.org/licenses/by/4.0/). 